\title{
Drumstick (Moringa oleifera) variation in biomass and total flavonoid content in Indonesia
}

\author{
RIDWAN $^{1,3, \vartheta}$, HAMIM $^{2, v v}$, SUHARSONO ${ }^{2}$, NURIL HIDAYATI ${ }^{3}$, INDRA GUNAWAN ${ }^{3}$ \\ ${ }^{1}$ Graduate Program in Plant Biology, Department of Biology, Faculty of Mathematics and Natural Sciences, Institut Pertanian Bogor. Jl. Agathis, IPB \\ University Darmaga Campus, Bogor 16680, West Java, Indonesia. Tel.: +62-251-8625481, Fax.: +62-251-8625708, "email: ridwan6words@ gmail.com \\ ${ }^{2}$ Departement of Biology, Faculty of Mathematics and Natural Sciences, Institut Pertanian Bogor. Jl. Agathis, IPB University Darmaga Campus, Bogor \\ 16680, West Java, Indonesia. Tel.: +62-251-8625481, Fax.: +62-251-8625708, "wemail: hamim@ipb.ac.id \\ ${ }^{3}$ Botany Division, Research Center for Biology, Indonesian Institute of Sciences. Jl. Raya Jakarta-Bogor Km. 46, Cibinong, Bogor 16911, West Java, \\ Indonesia
}

Manuscript received: 8 December 2020. Revision accepted: 30 December 2020.

\begin{abstract}
Ridwan, Hamim, Suharsono, Hidayati N, Gunawan I. 2021. Drumstick (Moringa oleifera) variation in biomass and total flavonoid content in Indonesia. Biodiversitas 22: 491-498. Utilization of a drumstick (Moringa oleifera Lam.) leaf has recently increased worldwide which consequently cause an increase in global demand. As a tropical country with large area, Indonesia has a great potential to become a center for drumstick cultivation and leaf production. Drumstick distribution scattered in almost all of the islands of Indonesia has another potential for obtaining superior genotype variabilities. The aim of this study was to select the drumstick accessions from several islands in Indonesia with high leaf biomass production and flavonoid content. This experiment was carried out in the field using ten accessions of drumsticks from ten islands in Indonesia, namely Sumatra, Java, Madura, Bali, Lombok, Sumbawa, Sumba, Kalimantan, Sulawesi, and Papua. Drumstick seeds were planted in polybags with a capacity of $10 \mathrm{~kg}$ and arranged using a randomized block design with three replications. The parameters observed were plant growth, biomass production, total flavonoid content, and antioxidant activity. The results of this study found that Sumatra accession was the accession that had the highest leaf biomass production in combination with the uppermost total flavonoid content and antioxidant activity compared to others. Sumatra accession is recommended as an excellent accession for cultivation with the aim of producing flavonoids.
\end{abstract}

Keywords: Antioxidant, bioactive compound, kelor, leaf production, Moringa

\section{INTRODUCTION}

Drumstick tree (Moringa oleifera Lam.) is a plant species belonging to Moringaceae originating from the Himalayan foothills, which include Pakistan, India, Nepal and Bangladesh. Currently, the drumstick tree is widely known and cultivated mainly in tropical territory (Abdullahi et al. 2013). The utilization of drumstick leaves has recently increased significantly as a material for food, medicine, cosmetics and has even been produced on an industrial scale (Sauveur et al. 2010, Gandji et al. 2018). This is likely due to increased knowledge about the nutritional content and pharmaceutical potential of drumstick leaf.

The nutritional content of the drumstick tree is reported to be much higher than that of other plants (Rockwood et al. 2013; Koul and Chase 2015; Gopalakrishnan et al. 2016). Asante et al. (2014) reported that the calcium content of drumstick leaf in Ghana is ranging from 1474 $\mathrm{mg} \mathrm{kg}^{-1}$ to $1880 \mathrm{mg} \mathrm{kg}^{-1}$. Ridwan and Witjaksono (2020) reported higher calcium content of drumstick leaf from Indonesia which reached 1776-2414 $\mathrm{mg} \mathrm{kg}^{-1}$. Several other reports regarding the high nutritional content of drumstick trees have also been published by Moyo et al. (2011), Melo et al. (2013), Isitua et al. (2015), and Brilhante et al. (2017). In addition, drumstick plants also contained various bioactive compounds that have pharmaceutical functions such as tannins, saponins, alkaloids, flavonoids, glycosides, and reducing sugars (Isitua et al. 2015). The most common bioactive compounds possessed by drumstick is flavonoid (Lin et al. 2018) in the form of quercetin, kaempferol, (Muhammad et al. 2016; Lin et al. 2018) and myricetin (Edwinanto et al. 2018) with a concentration of three times more than other vegetables such as Cabbage (Brassica oleracea), Spinach (Amaranthus gangeticus), Peas (Pisum sativum), Cauliflower (Brassica oleracea var. botrytis), and Broccoli (Brassica oleracea var. italica) (Pakade et al. 2013). The flavonoids are well known to have special function as anti-cancer by suppressing the growth and proliferation of cancer cells (Edwinanto et al. 2018).

The increase of the drumstick leaf utilization triggers the growth of market demand, while the production of drumstick in Indonesia is still low. In Indonesia, drumstick trees are mostly grown in human community yards and gardens by subsistent for one or two trees with no cultivation technology applied (Ridwan et al. 2018, unpublished data). Meanwhile, Indonesia with a large area and a suitable climate for drumstick trees have great potential to become the center of planting and producing the drumstick leaf. In terms of genetic resources, Indonesian archipelago also has great potential to have drumstick diversity, since this tree is spread almost throughout the archipelago (Riastiwi et al. 2018). Palada et al. (2015) reported that the production of drumstick leaves 
is greatly influenced by their genotype. In addition, the genotype also strongly determines bioactive content of the drumstick leaf which may differ from one to another. Drumstick leaf from India, Nicaragua, and Nigeria for example, contained total flavonoids of 21.0, 38.1, and 44.3 $\mathrm{g} \mathrm{kg}^{-1}$ respectively (Sidhuraju and Becker 2003), while drumstick leaf from several areas in Pakistan such as Nawabshah, Jamshoro, Chakwal, Balakot, and Mardaan contained even significantly higher than from India with the total content of $69.3,73.8,93.2,119.0$, and $125.3 \mathrm{~g} \mathrm{~kg}$ 1 , respectively (Iqbal and Bhanger 2006).

To the best of our knowledge, there were no studies on selection of drumstick genotype or accession, or provenance from Indonesia with high biomass production and total flavonoid content which can be recommended as high-quality drumstick plants for cultivation program. Therefore, this study aimed to obtain the accessions of drumstick trees from several islands in Indonesia with high leaf biomass production and total flavonoid content.

\section{MATERIALS AND METHODS}

The seeds of ten drumstick accessions were used in the experiment including Sumatra (Deli Serdang), Java (Bogor), Madura (Sumenep), Bali (Tabanan), Lombok (Kuta-Mandalika), Sumbawa (North Moyo), Sumba (Southwest Sumba), Kalimantan/Borneo (Mempawah), Sulawesi (Enrekang), dan Papua (Jayapura) obtained from Research Center for Biology, Indonesian Institute of Sciences. The drumstick seeds were washed in running water and then soaked in clean water for $1 \mathrm{~h}$. The seeds were then soaked in a solution of fungicide and bactericide $2 \mathrm{~g} / \mathrm{L}$ for $30 \mathrm{~min}$. This experiment was designed with a non-factorial randomized block design with treatment of different accessions repeated three times. A total of 6 seeds for each accession ( 2 seeds for each replication) were planted with a depth of $\pm 2 \mathrm{~cm}$ on a $35 \times 45 \mathrm{~cm}$ polybag containing a mixture of soil, manure, and roasted husk with a ratio of $2: 1: 1(\mathrm{v} / \mathrm{v} / \mathrm{v})$ for a total weight of $10 \mathrm{~kg}$. The humidity of the planting medium was maintained by watering every two days.

\section{Plant growth and morphology observation}

Plant morphological parameters include growth and biomass production measured during the experiment. The growth parameters were observed at the age of six months after planting (map) or two months after pruning, i.e. plant height, stem diameter, canopy diameter, number of branches, number and size of compound leaves, proportion of compound leaves senescence, and leaflet number and area. Plant height was measured from the ground to the tip of the youngest leaves. The stem diameter was measured at a height of $5 \mathrm{~cm}$ from the surface of the growing medium. The canopy diameter was observed by measuring the length of the canopy distribution from two perpendicular sides of the plant. The number of branches was counted manually to the branches that emerged from the main trunk after pruning. The number of compound leaves was counted manually to the leaves that still attached to the main stem and branches. Compound leaves size was measured to the length and width of the $4^{\text {th }}$ leaf counted from the shoot. The length of compound leaves was measured from the base of the leaves crate to the tip of the leaves, while the width of the leaves was measured at the widest part of the leaves. Leaf senescence observation was carried out by counting the number of yellowed compound leaves. The number and area of leaflets were observed in the $4^{\text {th }}$ compound leaves counting from the apex. The number of leaflets was calculated manually, while the area of leaflets was observed using ImageJ $1.47 \mathrm{v}$ software from the random samples of five leaflets photos taken using a Canon EOS M10 camera.

The observed plant biomass production consisted of leaflet dry weight, stem dry weight, root dry weight, and total dry weight. The dry weights of leaflets and stems were obtained from the harvest at the age of 2 map, 4 map, and 6 map. The harvest was done by cutting the stem at a height of $20 \mathrm{~cm}$ from the planting medium surface. Compound leaves were taken manually and then washed in running water, then the leaflets were separated manually as well. Leaflets and stems were put in different paper envelopes with 0.5 folio size, then dried in an oven at $60^{\circ} \mathrm{C}$ for $24 \mathrm{~h}$ (leaflets) and $72 \mathrm{~h}$ (stems), then weighed with an analytical balance. Root dry weight was observed destructively at the age of 6 maps. Tuberous roots were washed and cut into small pieces before being put into a 0.5 folio size paper envelope, then dried in an oven at $60{ }^{\circ} \mathrm{C}$ for ten days (until constant weight).

\section{Determination of total flavonoid content}

Total flavonoid extraction was carried out following Vongsak et al. (2013). The clean fresh leaflets samples were dried in an oven at $60{ }^{\circ} \mathrm{C}$ for $24 \mathrm{~h}$. Dry leaflet samples were crushed and sieved at 20 mesh size. The powder was then stored in a closed container away from light before being extracted. Flavonoid extraction was carried out with $70 \%$ ethanol solvent. Drumstick leaflet powder was soaked in $70 \%(1: 40, \mathrm{w} / \mathrm{v})$ ethanol while shaking it at room temperature $\left(25^{\circ} \mathrm{C}\right)$ for $72 \mathrm{~h}$. The extract was then filtered and re-extracted in the same way until a concentrated extraction was obtained. Total flavonoids were determined using a colorimeter method adapted from Chatatikun and Chiabchalard (2013) with modifications. Quercetin standard solutions were made with stratified concentrations, i.e. $0,40,50,60,70,80,90$, and $100 \mu \mathrm{g}$ $\mathrm{mL}^{-1}$ dissolved in ethanol. A total of $50 \mu \mathrm{L}$ of extract $(1 \mathrm{mg}$ $\mathrm{mL}^{-1}$ ) and standard solution were added with $10 \mu \mathrm{L}$ of aluminum chloride $\left(\mathrm{AlCl}_{3}\right), 150 \mu \mathrm{L}$ of ethanol, and $10 \mu \mathrm{L}$ of $1 \mathrm{M}$ of Na-acetate, then shaken in a 96 well microplate for $40 \mathrm{~min}$ at room temperature and dark. The absorbance was read at a wavelength of $415 \mathrm{~nm}$ with ethanol blank. The total flavonoid content obtained was expressed in $\mathrm{mg}$ quercetin equivalent per-gram $\left(\mathrm{mg} \mathrm{g}^{-1}\right)$ of extract.

\section{Measurement of antioxidant activities}

Antioxidant activity was analyzed using Ferric Reducing Antioxidant Power (FRAP) method. A total of 5 $\mathrm{mg}$ of drumstick leaflet extract was dissolved in $5 \mathrm{~mL}$ of $96 \%$ ethanol, then $1 \mathrm{~mL}$ were taken and added $1 \mathrm{~mL}$ of 0.2 $\mathrm{M}$ phosphate buffer (pH 6.6) and $1 \mathrm{~mL} \mathrm{~K}_{3} \mathrm{Fe}(\mathrm{CN}) 61 \%$, 
then incubated for $20 \mathrm{~min}$ at $50^{\circ} \mathrm{C}$. A total of $1 \mathrm{~mL}$ of TCA was added before centrifuged at $3000 \mathrm{rpm}$ for $10 \mathrm{~min}$. The supernatant was taken as much as $1 \mathrm{~mL}$, and were added 1 $\mathrm{mL}$ of distilled water and $0.5 \mathrm{~mL}$ of $0.1 \% \mathrm{FeCl}_{3}$. The solution was left to stand for $10 \mathrm{~min}$ before measuring the absorbance at a wavelength of $720 \mathrm{~nm}$ with the oxalate solution as a blank. Calibration curves were made using ascorbate solution with various concentration levels. Based on the absorbance value, the $\mathrm{IC}_{50}$ value was calculated to determine the antioxidant activity.

\section{Data analysis}

Data were analyzed with One-Way ANOVA using software SPSS for Windows version 16 at $95 \%$ confidence level $(\alpha=0.05)$. The differences among mean values were detected with DMRT (Duncan Multiple Range Test) at the same confidence level.

\section{RESULTS AND DISCUSSION}

\section{Morphological parameters}

There was a fairly large variety of morphological parameters among the ten accessions based on visual observation. Statistical analysis showed that the plant height, canopy diameter, stem diameter, and number of branches were significantly different $(\mathrm{P}<0.05)$ among the accessions. The tallest plant was Madura accession, but not significantly different to Bali, Sumba, Sumbawa, Kalimantan, Java, and Sumatra accessions. Lombok, Sulawesi, and Papua accessions were shorter and significantly different from Madura accession (Figure 1.A). The largest canopy diameter was owned by accessions of Sumba and Sumbawa, but not significantly different from accessions of Madura, Papua, Lombok, Java, and Sumatra. Bali accession had the smallest canopy diameter, followed by Sulawesi and Kalimantan (Figure 1.B). The accessions with the largest stem diameter were Java and Sulawesi, but not significantly different from Madura and Sumbawa. Accessions with the smallest stem diameter were Bali, followed by Lombok, Papua, Kalimantan, and Sumba. Sumatra accession had a stem diameter value between those two groups (Figure 1.C). Accessions with the highest number of branches were Bali and Kalimantan, while Sumba accession was the fewest (Figure 1.D).

Among the ten drumstick accessions, the differences in leaf character were also significantly found. Bali accessions had the highest compound leaves number followed by Kalimantan, Sulawesi, Java, Sumatra, Madura, Lombok, and Sumbawa, while the lowest was Sumba accessions followed by Papua (Figure 2.A). The longest and widest compound leaves were shown by Sumba accessions followed by Sumbawa, while the shortest and narrowest was shown by Bali accession (Figures 2.B and 2.C).


Figure 1. Plant growth measurement of ten accessions of Moringa oleifera from Sumatra (Sm), Java (J), Madura (M), Bali (B), Lombok (L), Sumbawa (Sb), Sumba (S), Kalimantan (K), Sulawesi (Si), and Papua (P) at 6 months after planting. A. Plant height, B. Canopy diameter, C. Stem diameter, D. Brach number. Different letters indicate significant differences at $\mathrm{p}<0.05$ DMRT. 
The experiment also observed proportion of leaf senescence to analyze total active leaves among the accessions. The lowest proportion of senescence was shown by accession of Sumatra followed by Sulawesi and Sumba, while the highest was shown by accessions of Bali followed by Kalimantan, Madura, Papua, and Lombok (Figure 2.D). Accessions with the highest number of leaflets were shown by Java accession followed by Sumba, while the lowest was Bali accession (Figure 2.E). The widest leaflets were indicated by Sumatra accession followed by Lombok, Bali, and Papua accessions, while accessions with the narrowest leaflets were Java followed by Kalimantan and Madura (Figure 2.F).
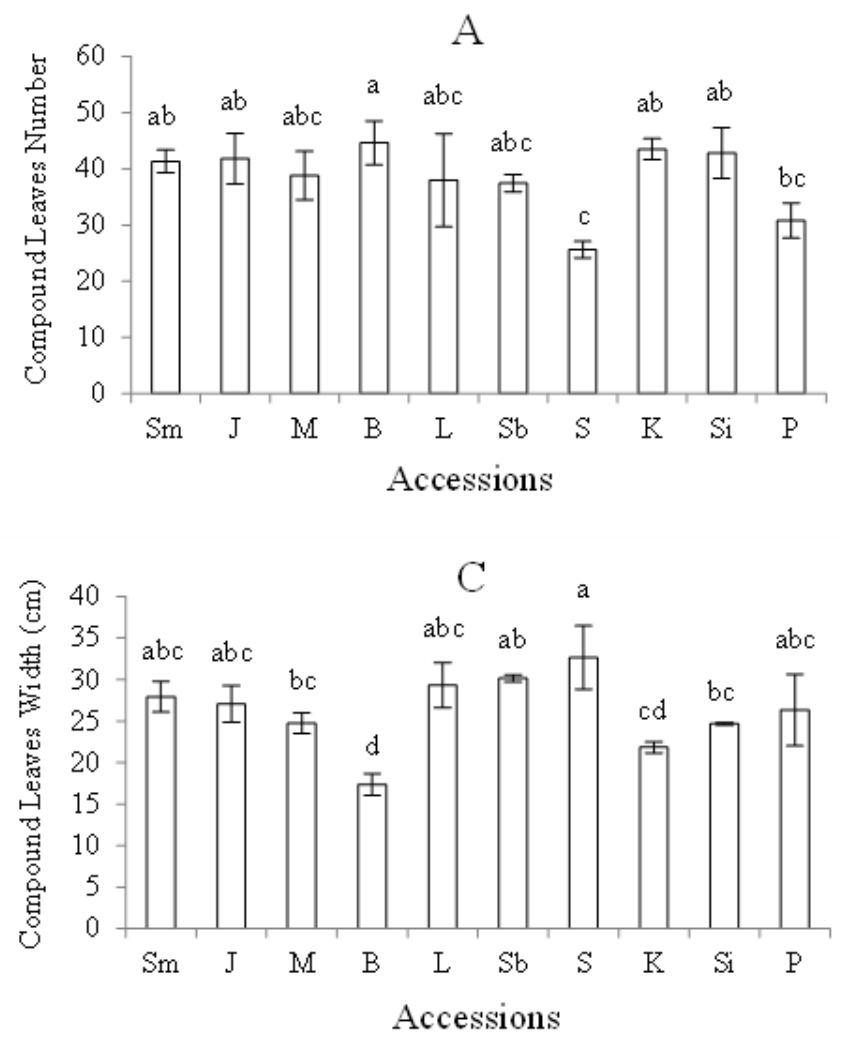
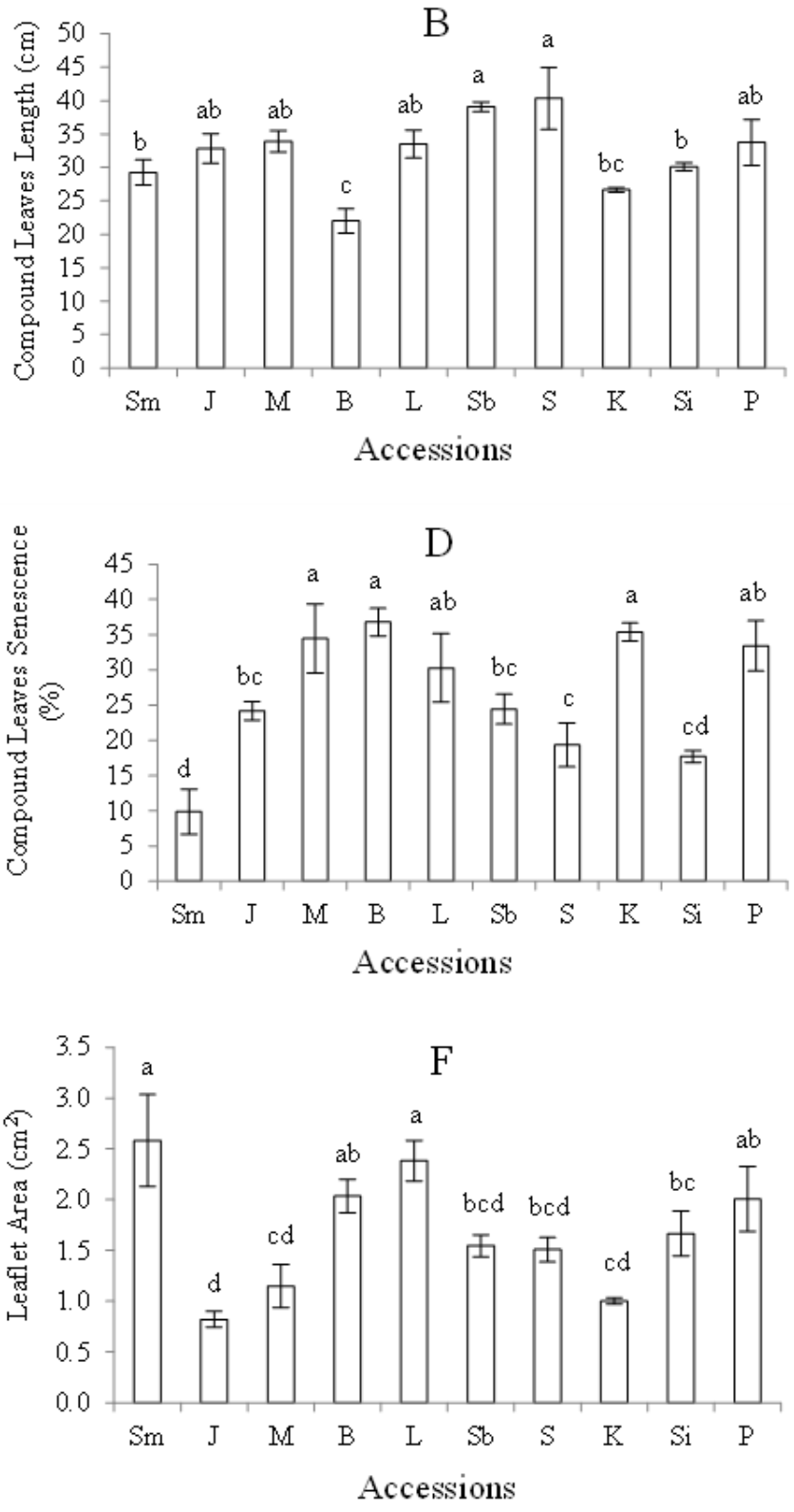

Figure 2. Compound leaves and leaflet measurement of ten accessions of Moringa oleifera from Sumatra (Sm), Java (J), Madura (M), Bali (B), Lombok (L), Sumbawa (Sb), Sumba (S), Kalimantan (K), Sulawesi (Si), and Papua (P) at 6 months after planting. A. Compound leaves number, B. Compound leaves length, C. Compound leaves width, D. Compound leaves senescence, E. Leaflet number, F. leaflet area. Different letters indicate significant differences at $\mathrm{p}<0.05$ DMRT. 


\section{Biomass production}

The leaflet is the main part of drumstick that is most important due to most widely used. This causes the leaflet dry weight in this study to become the main production. However, stem dry weight, root dry weight, and total biomass dry weight were also observed. The dry weight of leaflets, stems, roots, and total biomass showed significant differences among accessions. The highest dry weight of leaflets was shown by Sumatra accession and followed by Java, while accession with the lowest leaflet dry weight was Bali. Other accessions that have quite high leaflet production were Madura, Lombok, Sumba, Kalimantan, and Sumbawa (Figure 3.A). The accession with the highest stem dry weight was Sulawesi, while the lowest was Bali (Figure 3.B). Root dry weight and total biomass dry weight showed the same pattern, Sumbawa accession had the highest root biomass and total biomass, while Sulawesi had the lowest followed by Papua and Kalimantan (Figures 3.C and 3.D). The same pattern indicates that total biomass seems to be affected mainly by tuberous root dry weight.

\section{Total flavonoid content and antioxidant activities}

Total flavonoid content of drumstick leaf was also significantly different $(\mathrm{p}<0.05)$ among the accessions.
Sumatra accession had the highest total flavonoid content, Java and Madura had the lowest, while Kalimantan, Sumba, Papua, and Bali had a moderate level (Figure 4.A). The antioxidant activity of the ten accessions of drumsticks also showed significant differences. Sumatra accession had the lowest $\mathrm{IC}_{50}$ score compared to other accessions. Accessions with $\mathrm{IC}_{50}$ value near Sumatra were Madura and Sumba. Accessions with the highest $\mathrm{IC}_{50}$ value were shown by Papua, followed by Kalimantan and Lombok (Figure 4.B).

\section{Discussion}

This experiment was carried out to select the drumstick accessions from several islands in Indonesia based on biomass production and the content of leaf total flavonoids. The ten accessions observed in this experiment showed different morphological, biomass and flavonoid content becoming a good material for genotype screening to find drumsticks with higher biomass production and bioactive compound. Among the ten accessions, the highest leaf biomass production was only significantly found in Sumatra (34.69 g per plant) and Java (34.48 g per plant). This was supported by their superior growth characters, especially leaves (Figure 2).
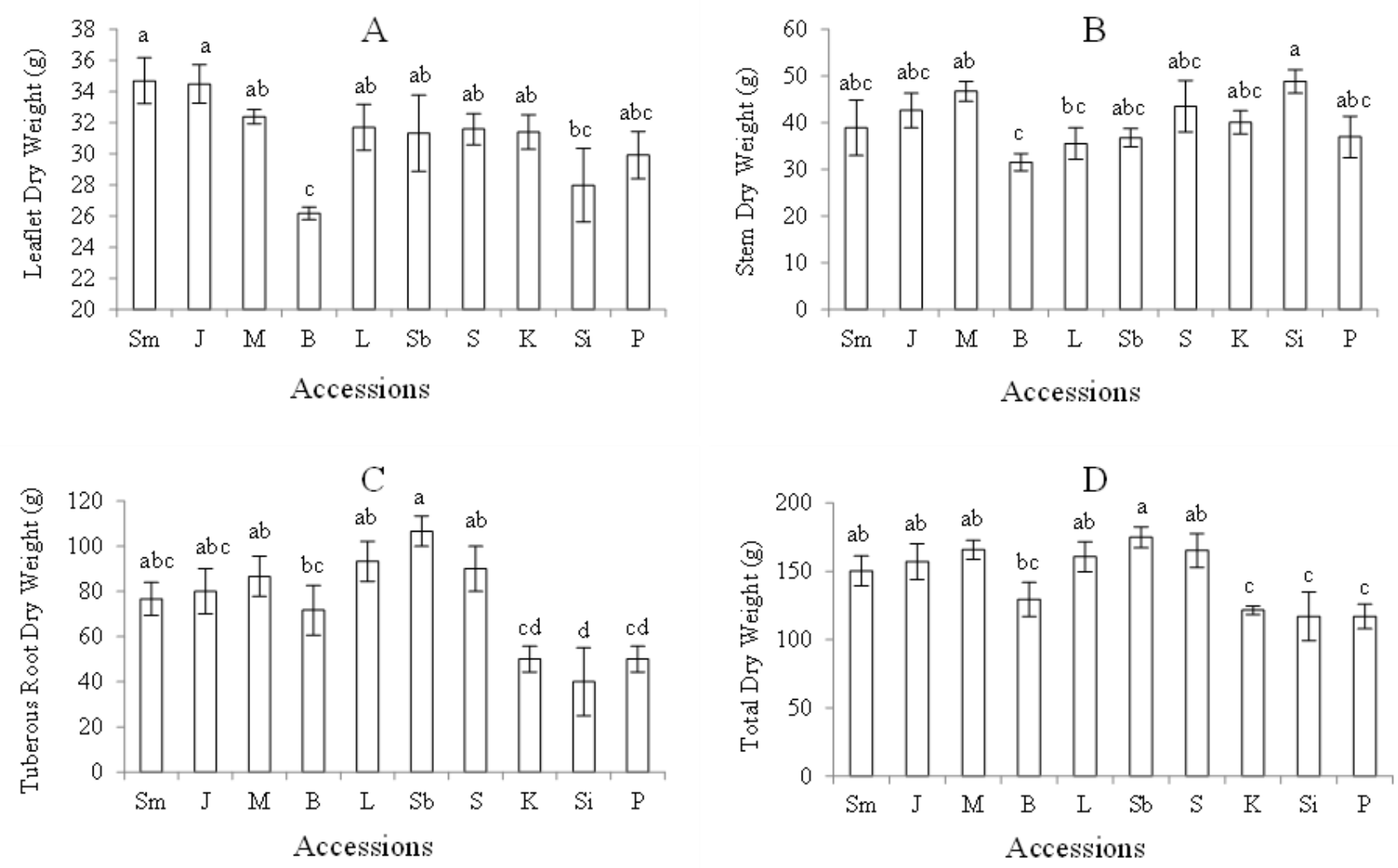

Figure 3. Biomass production of ten accessions of Moringa oleifera from Sumatra (Sm), Java (J), Madura (M), Bali (B), Lombok (L), Sumbawa (Sb), Sumba (S), Kalimantan (K), Sulawesi (Si), and Papua (P) at 6 months after planting. A. Leaflet dry weight, B. Tuberous root dry weight, C. Stem dry weight, D. Total biomass dry weight. Different letters indicate significant differences at $\mathrm{p} \leq 0.05 \mathrm{DMRT}$. 

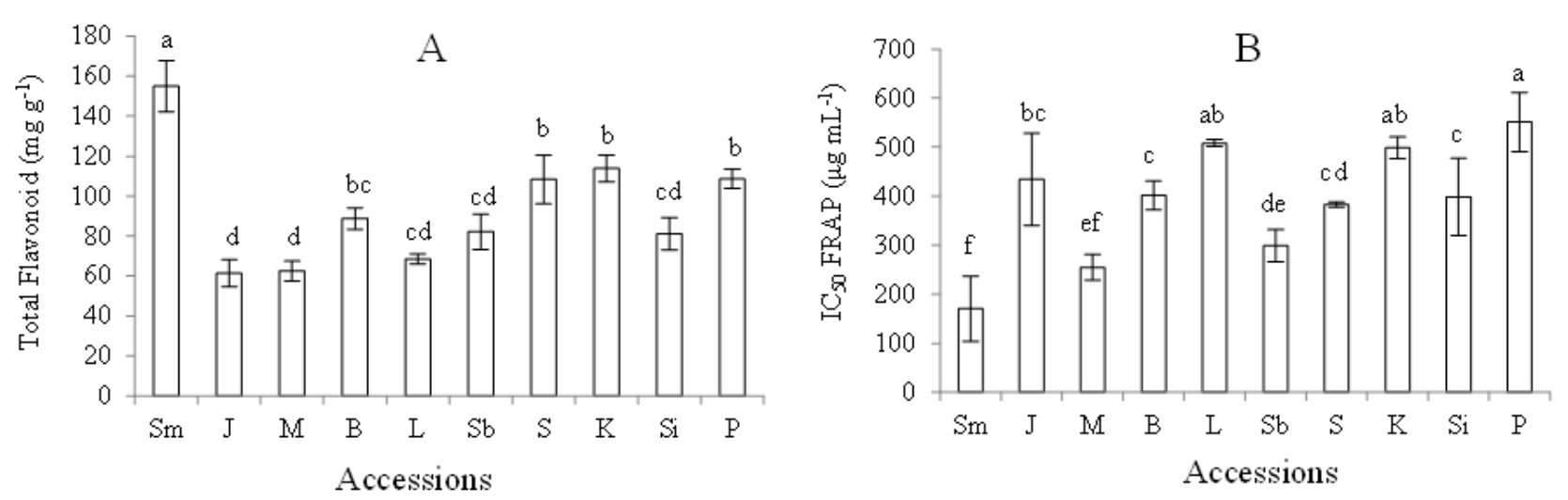

Figure 4. Total flavonoid content and antioxidant activity of Moringa oleifera leaves from accessions of Sumatra (Sm), Java (J), Madura (M), Bali (B), Lombok (L), Sumbawa (Sb), Sumba (S), Kalimantan (K), Sulawesi (Si), and Papua (P). A. Total flavonoid, B. Antioxidant activity. Different letters indicate significant differences at $\mathrm{p} \leq 0.05$ DMRT.

Sumatra accession had a relatively large leaflet number and size with lower proportion of compound leaves senescence. Java accession had the largest number of leaflet, but the size of the leaflets was small. Sumba accession also had a large number of leaflets, almost the same as the Java accession, but the number of compound leaves of this accession was less (Figure 2.A). Although Sumatra and Java accessions had the highest leaflet biomass production, but only Sumatra accession contained much higher flavonoid compounds than other accessions, while Java accessions contained the lowest together with Madura accession. This finding provides evidence that many different genotypes of drumsticks were found in Indonesia archipelago which exhibited different growth and biomass production as well as total content of flavonoids.

Drumstick is a fast-growing plant that can produce biomass in large amount. The present study found that the production of drumstick biomass had quite a large variation among accessions. There were several reports that are in accordance with the results of this study. Ebou Dao and Walsh (2017) reported the differences in the genotype of drumstick plants expressed to difference in leaf size characters that affect biomass production. Wider leaflet leads to greater leaflet biomass production. Huque et al. (2017) also reported that the fresh biomass production of drumstick leaf has a fairly large variation among cultivars, ranged from $10.6 \mathrm{t} \mathrm{h}^{-1} \mathrm{y}^{-1}$ to $38.7 \mathrm{t} \mathrm{h}^{-1} \mathrm{y}^{-1}$. Gadzirayi et al. (2019) also reported that in plantings with a distance of 20 $\times 20 \mathrm{~cm}$, the biomass production of drumstick leaves originating from Malawi was $36 \%$ higher than that from Mutoko.

Drumstick is also widely known to contain high bioactive flavonoid compounds (Pakade et al. 2013). In this study, the total flavonoid content of the ten accessions was found to be quite varied, ranging from $61.4 \mathrm{mg} / \mathrm{g}$ (Java accession) to $154.9 \mathrm{mg} \mathrm{g}^{-1}$ extract (Sumatra accession). Several previous research results which also stated that the flavonoid content of drumstick leaf was quite varied between genotypes or provenances have also been reported. Sidhuraju and Becker (2003) reported that there were significant variations in the total flavonoid content in drumstick leaves from India $\left(21.0 \mathrm{~g} \mathrm{~kg}^{-1}\right)$, Nicaragua (38.1 $\mathrm{g} \mathrm{kg}^{-1}$ ), and Nigeria $\left(44.3 \mathrm{~g} \mathrm{~kg}^{-1}\right)$. Drumstick leaves from several regions in Pakistan even contain much higher total flavonoids ranging from $69.3 \mathrm{~g} \mathrm{~kg}^{-1}$ dry weight to $125.3 \mathrm{~g}$ $\mathrm{kg}^{-1}$ dry weight (Iqbal and Bhanger 2006). Panwar and Mathur (2019) also reported that 57 accessions of drumsticks from various regions in India contained highly variable routine flavonoids ranging from close to $0 \mathrm{mg} \mathrm{kg}^{-1}$ dry weight (undetectable) to $60 \mathrm{mg} \mathrm{kg}^{-1}$ dry weight. Different flavonoid content due to genotype differences has also been reported in other plants, such as Cyclocarya paliurus (Fang et al. 2011), Chinese Dwarf Cherry (Wang et al. 2018), Balanites aegyptiaca (Khamis et al. 2020), and Cleome gynandra (Somers et al. 2020). Apart from Sumatra, there were several accessions with relatively high levels of flavonoids content that have the potential for genetic improvement in the future, namely Kalimantan, Papua, and Sumba. The flavonoid content of these accessions could also possibly be increased by modifying the growing environment such as drought (Omidi et al. 2018), salinity (Golkar and Taghizadeh, 2018), light (Pan and Guo, 2016), etc.

The antioxidant activity test results using the FRAP method showed that the $\mathrm{IC}_{50}$ value of drumstick leaf extract from the ten accessions varied in the range of $170.44 \mu \mathrm{g}$ $\mathrm{mL}^{-1}$ to $508.05 \mu \mathrm{g} \mathrm{mL}^{-1}$. Sumatra accession had the lowest $\mathrm{IC}_{50}$ value compared to other accessions, which means that the Sumatra accession had the highest antioxidant activity compared to other accessions. The $\mathrm{IC}_{50}$ value is the concentration of material needed to neutralize free radicals as much as $50 \%$ (Setiawan et al. 2018). Turkoglu et al. (2007) also stated that the low $\mathrm{IC}_{50}$ value in the antioxidant activity test reflects the high antioxidant activity in a sample. The $\mathrm{IC}_{50}$ value of the leaf extract of all drumstick accessions in this experiment was much lower than the $\mathrm{IC}_{50}$ value of drumstick leaf extract reported by Anigboro et al. (2019) of $3190 \mu \mathrm{g} \mathrm{mL}^{-1}$ and Sarwar et al. (2017) amounted to $831.67 \mu \mathrm{g} \mathrm{mL}^{-1}$ to $1653 \mu \mathrm{g} \mathrm{mL}-1$. It means that the antioxidant activity of drumstick leaf extracts of all accessions used in this experiment was quite high, especially Sumatra accessions. 
Based on the results, it can be concluded that the drumstick plants from several islands in Indonesia have variable characteristics based on growth, biomass production, total flavonoid content, and antioxidant activity. Sumatra accession is the best accession based on those characters. Sumatra accession has great potential to be further developed and used in drumstick cultivation for the production of flavonoid bioactive compounds.

\section{ACKNOWLEDGEMENTS}

This research was funded by The Ministry of Research and Technology/National Research and Innovation Agency through Doctoral Dissertation Research Program, with the Grant number of 1/E1/KP.PTNBH/2020. We would like to appreciate Kania Dewi Renganis and M. Maftuchin Sholeh for their technical assistance.

\section{REFERENCES}

Abdullahi IN, Ochi K, Gwaram AB. 2013. Plant population and fertilize application effects on biomass productivity of Moringa oleifera in North-Central Nigeria. Peak J Agric Sci 1 (6): 94-100.

Anigboro AA, Avwioroko OJ, Ohwokevwo OA, Pessu B. 2019. Bioactive components of Ficus exasperata, Moringa oleifera and Jatropha tanjorensis leaf extracts and evaluation of their antioxidant properties. EurAsia J BioSci 13: 1763-1769.

Asante WJ, Nasare IL, Dery DT, Boadu KO, and Kentil KB. 2014 Nutrient composition of Moringa oleifera leaves from two agroecological zones in Ghana. Afr J Plant Sci 8 (1): 65-71. DOI 10.5897/AJPS2012.0727

Brilhante RSN, Sales JA, Pereira VS, Castelo-Branco DdSCM, Cordeiro RdA, Sampaio CMdS, Paiva MdAN, do Santos JBF, Sidrim JJC, Rocha MFG. 2017. Research advances on the multiple uses of Moringa oleifera: A sustainable alternative for socially neglected population. Asian Pacific J. of Trop. Med. 10 (7): 621-630. DOI: 10.1016/j.apjtm.2017.07.002.

Chatatikun M, Chiabchalard. 2013. Phytochemical screening and free radical scavenging activities of orange baby carrot and carrot (Daucus carota Linn.) root crude extracts. J Chem Pharmaceut Res 5 (4): 97 102.

Ebou Dao MC, Walsh D. 2017. Correlation between seed characteristics and biomass production of Moringa oleifera provenances grown in Ouagadougou, Burkina Faso. Afr J Plant Sci 11 (11): 385-393. DOI: 10.5897/AJPS2017.1579

Edwinanto L, Septiadi E, Nurfazriah LR, Anastasya KS, Pranata P. 2018 Phytochemical features of Moringa oleifera leaves as anticancer. A Review Article. J Med Health 2 (1): 680-688.

Fang S, Yang W, Chu X, Shang X, She C, Fu X. 2011. Provenance and temporal variations in selected flavonoids in leaves of Cyclocarya paliurus. Food Chem 124: 1382-1386. DOI 10.1016/j.foodchem.2010.07.095.

Gadzirayi CT, Kubiku F, Mupangwa J, Masamha B, Majuru L. 2019. The effect of provenance, plant spacing and cutting interval on leaf biomass yield of Moringa oleifera Lam. East Afr. Agric. Forest. J. 83 (1): 25-33. DOI: 10.1080/00128325.2018.1511174

Gandji K, Chadare EJ, Idohou R, Salako VK, Assogbadjo AE, Glele Kakai RL, 2018. Status and utilisation of Moringa oleifera Lam: A Review. Afr. Crop Sci. J. 26 (1): 137-156. DOI: 10.4314/acsj.v26i1.10.

Golkar P, Taghizadeh, 2018. In vitro evaluation of phenolic and osmolite compounds, ionic content, and antioxidant activity in safflower (Carthamus tinctorius L.) under salinity stress. Plant Cell Tiss Org Cult. DOI: 10.1007/s11240-018-1427-4.

Gopalakrishnan L, Doriya K, Kumar DS. 2016. Moringa oleifera: A review on nutritive importance and its medicinal application. Food Sci Human Wellness 5: 49-56. DOI: 10.1016/j.fshw.2016.04.001.
Huque KS, Bashar MK, Sarker NR, Sultana N, Rot BK, Amhed S, Makkar HPS. 2017. Annual biomass production, chemical composition and in-sacco degradability of different cultivar of Moringa oleifera. Intl J Environ Agric Biotechnol 2 (2): 864-873. DOI: $10.22161 /$ ijeab/2.2.39.

Ierna A, Mauro RP, Mauromicale G. 2012. Biomass, grain and energy yield in Cyana cardunculus L. as affected by fertilization, genotype and harvest time. Biomass Bioenerg 36: 404-410. DOI:10.1016/j.biombioe.2011.11.013.

Iqbal S, Bhanger MI. 2006. Effect of season and production location on antioxidant activity of Moringa oleifera leaves grown in Pakistan. J Food Comp Ana. 19: 544-551. DOI: 10.1016/j.jfca.2005.05.001.

Isitua CC, Muros-Lozano MJS, Jaramillo CJ, Dutan F. 2015. Phytochemical and nutritional properties of dried leaf powder of Moringa oleifera Lam. from Machala el Oro Province of Ecuador. Asian J. Plant Sci. Res. 5 (2): 8-16.

Khamis G, Saleh AM, Habeeb TH, Hozzein WN, Wadaan MAM, Papenbrock J, Abdelgawad H. 2020. Provenance effect on bioactive phytochemicals and nutritional and health benefits of the desert date Balanites aegyptiaca. J. Food Biochem. e13229: 1-13. DOI: $10.1111 /$ jfbc. 13229

Koul B, Chase N. 2015. Moringa oleifera Lam.: Panacea to several maladies. J. Chem. Pharm. Res., 7 (6): 687-707.

Krishnamurthy L, Serraj R, Hash CT, Dakheel AJ, Reddy BV. 2007. Screening sorghum genotypes for salinity tolerant biomass production. Euphytica156: 15-24. DOI 10.1007/s10681-006-9343-9.

Lin M, Zhang J, Chen X. 2018. Bioactive flavonoids in Moringa oleifera and their health-promoting properties. J Func Food 47: 469-479. DOI: 10.1016/j.jff.2018.06.011

Melo V, Vargas N, Quirino T, Calvo CMC. 2013. Moringa oleifera L. An underutilized tree with macronutrients for human health. Emir. J. Food Agric. 25 (10): 785-789. DOI: 10.9755/ejfa.v25i10.17003.

Moyo B, Masika PJ, Hugo A, and Muchenje V. 2011. Nutritional characterization of Moringa (Moringa oleifera Lam.) leaves. Afr. J. Biotechnol. 10 (60):12925-12933. DOI: 10.5897/AJB10.1599.

Muhammad HI, Asmawi MZ, Khan NAK. 2016. A Review on promising phytochemical, nutritional and glycemic control studies on Moringa oleifera Lam. in tropical and sub-tropical regions. Asian Pac J Trop Biomed 6 (10): 896-902. DOI: 10.1016/j.apjtb.2016.08.006.

Omidi JF, Shoja MH, Sariri R. 2018. Effect of water-deficit stress on secondary metabolites of Melissa officinalis L.: role of exogenous salicylic acid. Caspian J Environ Sci 16 (2): 121-134.

Pakade V, Chimuka L, Cukrowska. 2013. Comparison of antioxidant activity of Moringa oleifera and selected vegetables in South Africa. S A J Sci 109: 1-5. DOI: 10.1590/sajs.2013/1154

Palada MC, Ebert AW, Yang RY, Chang LC, Chang J, Wu DL. 2015. Progress in research and development of moringa at the World Vegetable Center. Proceeding I International Symposium on Moringa. Acta Hortic 1158. ISHS 2017. 15 November 2015. DOI 10.17660/ActaHortic.2017.1158.49. [Philipines].

Pan J, Guo B. 2016. Effects of light intensity on the growth, photosynthetic characteristics, and flavonoid content of Epimedium pseudowushanense B.L. Guo. Molecules 21: 1475. DOI: 10.3390/molecules21111475.

Panwar A, Mathur J. 2019. Genetic and biochemical variability among Moringa oleifera Lam. accessions collected from different agroecological zones. Genome 63 (3): 169-177. DOI: 10.1139/gen-20190102 .

Riastiwi I, Damayanto IPGP, Ridwan, Handayani T, Leksonowati A. 2018. Moringa oleifera distribution in Java and Lesser Sunda Islands attributed with annual rainfall. Biosaintifika 10 (3): 613-621. DOI: 10.15294/biosaintifika.v10i3.16115.

Ridwan, Witjaksono. 2020. Induction of autotetraploid moringa plant (Moringa oleifera) using oryzalin. Biodiversitas 21 (9): 4086-4093. DOI: $10.13057 /$ biodiv/d210920

Rockwood JL, Anderson BG, Casamatta DA. 2013. Potential uses of Moringa oleifera and an examination of antibiotic efficacy conferred by $M$. oleifera seed and leaf extracts using crude extraction techniques available to underserved indigenous populations. Intl $\mathrm{J}$ Phytother Res 3 (2): 61-71.

Sarwar M, Ali A, Nouman W, Arshad MI, Patra JK. 2017. Compost and synthetic fertilizer affect vegetative growth and antioxidant activities of Moringa oleifera. Intl J Agric Biol 19: 1293-1300. DOI: 10.17957/IJAB/15.0465.

Sauveur AdS, Broin M, Noamesi S, Amaglo N, Adevu M, GloverAmengor M, Dosu G, Adjepong P, Adam S, Attipoe P. 2010. 
Growing and Processing Moringa Leaves. Moringanews/Moringa Association of Ghana, Ghana.

Setiawan F, Yunita O, Kurniawan. 2018. Antioxidant activity test of secang wood ethanol extract (Caesalpinia sappan) using the DPPH, ABTS, and FRAP. Media Pharmaceutica Indonesiana 2 (2): 82-89. DOI: $10.24123 / \mathrm{mpi} . \mathrm{v} 2 \mathrm{i} 2$.

Siddhuraju P, Becker K. 2003. Antioxidant properties of various solvent extracts of total phenolic constituents from three different agroclimatic origins of drumstick tree (Moringa oleifera Lam.) leaves. J Agric Food Chem 51: 2144-2155. DOI: 10.1021/jf020444+

Somers B, Dinissa FF, Wu Q, Simon JE. 2020. Elemental micronutrients, antioxidant activity, total polyphenol, and total flavonoid content of selected spider plant accessions (Cleome gynandra) grown in Eastern
Africa and the Eastern United States. J Med Active Plants 9 (3): 157165. DOI: $10.7275 /$ jnrp-3y92.

Turkoglu A, Emin M, Mercan N. 2007. Food chemistry antioxidant and antimicrobial activities of Laetiporus sulphureus (Bull.) Murrill. Food Chem 101: 267-273. DOI: 10.1016/j.foodchem.2006.01.025.

Vongsak B, Sithisarn P, Mangmool S, Tongpraditchote S, Wongkrajang Y, Gritsanapan W. 2013. Maximizing total phenolics, total flavonoids content and antioxidant activity of Moringa oleifera leaf extract by the appropriate extraction method. Industr Crops Prod 44: 566-571. DOI: 10.1016/j.indcrop.2012.09.021.

Wang P, Mu X, Du J, Gao YG, Dai D, Jia L, Zhang J, Ren H, Xue X. 2018. Flavonoid content and radical scavenging activity in fruits of Chinese dwarf cherry (Cerasus humilis) genotypes. J For Res 29 (1): 55-63. DOI: 10.1007/s11676-017-0418-3. 